\title{
Correlation Between Physical Activity and Health Status Among Elderly with Diabetes
}

\author{
$1^{\text {st }}$ Ema Wahyu Ningrum \\ Nursing Department \\ Harapan Bangsa University \\ Purwokerto, Indonesia \\ ema@uhb.ac.id
}

\author{
$2^{\text {nd }}$ Amin Susanto \\ Nursing Department \\ Harapan Bangsa University \\ Purwokerto, Indonesia \\ amin@uhb.ac.id \\ INTRODUCTION
}

\begin{abstract}
Epidemiological studies show that the prevalence of diabetes mellitus and impaired glucose tolerance (GTG) increase in line with the age. The increase in the prevalence of non-communicable diseases is associated with changes in lifestyle, including smoking, consumption of alcoholic beverages, physical activity, and eating patterns which is low in vegetables and fruits, obesity, hypertension, hypercholesterolemia. This study was aimed to determine the relationship between physical activity with the health status of elderly diabetes mellitus patients. This research was a quantitative study with cross sectional design. The sampling technique in this study used quota sampling. The samples were 50 elderly patients with Diabetes Mellitus. Univariate data analysis was used to look for frequency distribution, bivariate analysis used was chi square, and data normality was tested using Wilk Shappiro test. Physical activity data was collected by using a questionnaire. Nutritional status data was performed by anthropometric examination to determine BMI and waist circumference. Data on random blood sugar levels and total blood cholesterol levels were obtained using easy touch sticks and the results of the study resulted in the majority of DM patients aged $\geq 60$ years $(60 \%)$, having elementary education (74.0\%), having a family history of Diabetes Mellitus (62 \%), female sex (92\%), mostly having good diet (58.0\%), poor physical activity (58\%), have diabetes mellitus blood sugar levels (84.0\%), fat body mass index (36\%), high limit cholesterol levels (46\%), and central obesity $(84 \%)$. Physical activity related to health status at fasting blood sugar levels ( $p$ value $=0.042)$ was not related to cholesterol levels ( $p$ value $=0.758$ ), not related to obesity ( $p$ value $=1,000)$, and related to central obesity $(p$ value $=0.015)$.
\end{abstract}

Keywords: physical activity, health status, diabetes mellitus, elderly
Diabetes Mellitus (DM) is one of the major health problems. The International Diabetes Federation (IDF) estimates that there are 382 million people living with diabetes in the world in 2013. By 2035 that number is estimated to increase to 592 million. It is estimated that of the 382 million people, 175 million of them have not been diagnosed, so that the threat of progressive progression into complications is unnoticed and without prevention [1]. Indonesia ranks the $6^{\text {th }}$ in the number of Diabetes Mellitus events in the world [2] and based on 2018 Riskesdas data, diabetes mellitus rose from $6.9 \%$ to $8.5 \%$ [3].

Epidemiological studies show that the prevalence of both diabetes mellitus and impaired glucose tolerance (GTG) increase with age, settling before finally decreasing. Based on WHO data it was found that after reaching the age of 30 years, blood glucose levels would rise 1-2 $\mathrm{mg} \%$ / year during fasting and it would rise by $5-6 \mathrm{mg} \%$ / year at 2 hours after eating. Along with the process of aging, more and more elderly people are at risk of developing DM, so that now the term prediabetes is known.

Prediabetes is a condition of high fasting blood sugar 100-125mg / dL or impaired glucose tolerance (blood sugar levels 140-199 mg / dL, 2 hours after loading $75 \mathrm{~g}$ glucose). When the sugar level reaches $\geq 200 \mathrm{mg} / \mathrm{dL}$, it is included in the Diabetes Mellitus class. Based on the results of Riskesdas 2018, the highest prevalence of Diabetes Mellitus in the age range of 55-74 years was $19.6 \%$. The prediabetes proportion with Disturbed Sugar Tolerance (TGT) and Disturbed Fasting Blood Sugar (GDPT) in the age range $65-74$ years by $37.5 \%$. 
Diabetes Mellitus is usually called the silent killer because this disease can affect all organs of the body and cause various kinds of complaints. Diseases that will be caused including eye disorders, cataracts, heart disease, odd pain, sexual impotence, wounds that difficult to heal and rot / gangrene, lung infections, blood vessel disorders, strokes and so on. Frequently, DM sufferers undergo severe limb amputations due to decay [4]. Diabetes is also known as "Mother of Disease" because it is the mother of the other diseases such as hypertension, heart and blood vessel disease, stroke, kidney failure and blindness. Diabetes Mellitus can attack all levels of age and socioeconomic. If left unchecked, this disease can cause other complications that endanger health.

The increase in the prevalence of noncommunicable diseases is associated with the changes in lifestyle, including smoking, consumption of alcoholic beverages, physical activity, and eating patterns low in vegetables and fruits, obesity, hypertension, hypercholesterolemia. [1]. In line with the growth of the age, the elderlies suffer from physical and mental setbacks that have many consequences. In addition, the elderlies also experience special problems that are more susceptible to macrovascular and microvascular complications than DM and the presence of geriatric syndrome. Lifestyle modifications including maintaining a good diet, exercise and weight loss can decrease the progression of prediabetes to DM.

Obesity, especially those that are central (the stomach) is one of the factors that influence the emergence of DM. Excessive fat deposited in the body can cause insulin resistance which affects the blood sugar levels of people with diabetes mellitus [5]. One effort that can be done to reduce blood sugar levels in people with DM is to achieve good nutritional status. Determination of the ideal nutritional status used is the Body Mass Index (BMI). Research from Adnan (2013) shows that there is a relationship between BMI and blood sugar levels $(\mathrm{p}=0,000)[5]$.

Increased physical activity in the management of DM can improve lipid profile, blood glucose profile and weight loss. Physical activity is any kind of body movement that requires energy to do it. Planned and structured physical activity that involves repetitive body movements and is aimed to improving physical fitness is called exercise.

In the elderly there is a decrease in muscle mass, changes in blood distribution to muscles, a

decrease in $\mathrm{PH}$ in muscle cells, stiffer muscles, and there is also a decrease in muscle strength. The benefits of exercise in the elderly are that it can extend life, nourish the heart, muscles and bones, make the elderlies more independent, prevent obesity, reduce anxiety, and gain higher selfconfidence. However, because the elderlies are often found in comorbidities such as osteoporosis, Parkinson's, visual disturbances, and balance disorders, the type of exercise performed is more isotonic than isometric [6] i.e. meeting the FITT criteria (frequency, intensity, time, type) [7]. The results of research from Ririn (2013) showed that there were very significant differences in the lipid profile of DM type 2 clients before and after the intervention of healthy exercise of diabetes mellitus, with total cholesterol $(\mathrm{p}$ value $=$

0,000) and LDL (p value $=0,000)[8]$

Based on data from Padamara Public Health Centre, Purbalingga the number of DM sufferers recorded from Padamara Public Health Centre medical records in the January-December 2018 period was 105 visits or around $8.7 \%$ of the total number of public visits.

$\mathrm{DM}$ is the second highest number of noncommunicable diseases in this district. Based on this, researchers were interested in conducting research on the effect of physical activity to health status including blood sugar levels, cholesterol levels and nutritional status of elderly patients with diabetes mellitus. The research is needed because research on the physical activity pattern and health status based on the cholesterol level of DM patients are still rarely found.

\section{METHODOLOGY}

This research is a quantitative study with cross sectional design. The sampling technique in this study used quota sampling, with the total samples were 50 elderly patients with Diabetes Mellitus. Univariate analysis in the form of frequency distribution, bivariate analysis using chi square were used to analyse the data. The instruments were in the form of a dietary questionnaire, measurement of IMT with microtoise and stepping scales, measurement of pelvic circumference with metlin, examination of fasting blood sugar levels and blood cholesterol levels using easy touch sticks.

\section{RESULTS AND DISCUSSION}

In this study, the number of female DM sufferers was more than the male. This is in line with the research conducted by Lubis (2012) and Bintanah (2012) which shows that type 2 DM sufferers are more common in women compared to men.

Viewed from the age, this study showed that respondents aged $\geq 60$ years were the respondents having the largest percentage. This is in line with the results of Awad's study (2011) which shows an increase in the number of DM patients who were older than 50 years. The results of National Data 
diagnosed with DM but do not have a family history suffering from DM [9]

Riyadi and Widuri (2015) state that physical activity is a circadian rhythm in humans. Each individual has a unique rhythm in their daily lives in carrying out their activities, including for work, food, rest, recreation and so forth. In meeting these needs, coordination, security and efficiency are needed in order to produce good movements and to maintain balance during the activity.

According to the respondent's job, the most respondents were those who did not have a job. Research conducted by Balkau et al (2008) in 13 cities in Europe, it is concluded that the accumulation of daily physical activity is a major factor determining insulin sensitivity. In this study, the majority of respondents had a job as a housewife. Normal blood sugar level tends to increase gradually after reaching the age of 50 years. To reduce blood sugar level, physical activities such as exercise need to be done, because muscles use glucose found in the blood as energy.

People having one or more family members, including family members, parents, siblings or children suffering from DM, are 2 to 6 times more likely to have diabetes compared to people who do not have family members who have diabetes. The results of this study also showed that family history of DM was not the only factor associated with the incidence of DM. Based on the results of the study, there are $38 \%$ of respondents who have been

\begin{tabular}{l|c|c|} 
Table 1. Characteristics Of Respondents \\
\hline & $\mathrm{f}$ & $\%$ \\
\hline AGE (Years) & 6 & 12,0 \\
$<45$ years old & 14 & 28,0 \\
$45-59$ years old & 30 & 60,0 \\
$\geq 60$ years old & 50 & 100,0 \\
Total & & \\
EDUCATION & 37 & 74,0 \\
Elementary & 112 & 22,0 \\
Junior High School & 50 & 4,0 \\
Senior High School & & 100,0 \\
Total & & \\
HISTORY OF DM & 31 & 62,0 \\
Yes & 19 & 38,0 \\
No & 50 & 100,0 \\
Total & & \\
GENDER & 46 & 94,0 \\
Woman & 4 & 6,0 \\
Man & & \\
\hline
\end{tabular}

Table 2. Correlation Between Phisical Activity And Health Status Of Eldery

\begin{tabular}{|c|c|c|c|c|c|}
\hline \multirow{3}{*}{$\begin{array}{l}\text { Physical } \\
\text { Activity }\end{array}$} & & $\begin{array}{c}\text { Border to } \\
\text { height }\end{array}$ & $\begin{array}{c}\text { Hiper } \\
\text { cholesterolemia }\end{array}$ & Total & $p$-value \\
\hline & Enough & $\begin{array}{c}15 \\
(71,4 \%)\end{array}$ & $\begin{array}{c}6 \\
(28,6 \%)\end{array}$ & $\begin{array}{c}21 \\
(100 \%)\end{array}$ & 0,758 \\
\hline & Good & $\begin{array}{c}23 \\
(79,3 \%)\end{array}$ & $\begin{array}{c}6 \\
(20,7 \%)\end{array}$ & $\begin{array}{c}29 \\
(100 \%)\end{array}$ & \\
\hline \multirow{4}{*}{$\begin{array}{l}\text { Physical } \\
\text { Activity }\end{array}$} & \multicolumn{5}{|c|}{ Obesity } \\
\hline & & Normal & Obesit y & Total & $p$-value \\
\hline & Enough & $\begin{array}{c}17 \\
(81,0 \%)\end{array}$ & $\begin{array}{c}4 \\
(19,0 \%)\end{array}$ & $\begin{array}{c}21 \\
(100 \%)\end{array}$ & 1,000 \\
\hline & Good & $\begin{array}{c}24 \\
(82,8 \%)\end{array}$ & $\begin{array}{c}5 \\
(17,2 \%)\end{array}$ & $\begin{array}{c}29 \\
(100 \%)\end{array}$ & \\
\hline
\end{tabular}




\begin{tabular}{|c|c|c|c|c|c|}
\hline \multirow{3}{*}{$\begin{array}{l}\text { Physical } \\
\text { Activity }\end{array}$} & \multicolumn{5}{|c|}{ Central Obesity } \\
\hline & & $\begin{array}{l}\text { Central } \\
\text { Obesit y }\end{array}$ & Normal & Total & $p$-value \\
\hline & Enough & $\begin{array}{c}21 \\
(100 \%)\end{array}$ & $0(0 \%)$ & $\begin{array}{c}21 \\
(100 \%)\end{array}$ & 0,015 \\
\hline & Good & $\begin{array}{c}8 \\
(27,6 \%)\end{array}$ & $\begin{array}{c}21 \\
(72,4 \%)\end{array}$ & $\begin{array}{c}29 \\
(100 \%)\end{array}$ & \\
\hline Physica 1 & & Pre diabet es & Diabetes & Total & Pvalue \\
\hline & Enough & $\begin{array}{c}10 \\
(47,6 \%)\end{array}$ & $\begin{array}{c}11 \\
(52,4 \%)\end{array}$ & $\begin{array}{c}21 \\
(100 \%)\end{array}$ & 0,042 \\
\hline & Good & 23 & 6 & 29 & \\
\hline
\end{tabular}

Based on statistical tests, the result shows there is a relationship between physical activity and blood sugar level $(\mathrm{p}=0.042)$. This is in line with the theory which states that the intensity of physical

activity will affect blood sugar levels. Mild intensity in people with DM can reduce glucose. According to Plotnikoff (2006, in Mala Azitha, 2018), physical activity is the key in managing diabetes mellitus, especially as a controll of blood sugar, such as reducing hyperinsulinemia, increasing insulin sensitivity, lowering body fat, and lowering blood pressure. [10] Statistical test results showed that there was no relationship between physical activity and cholesterol levels $(\mathrm{p}=0.758)$. This is not in line with research from Sumosardjuno (2007 in Ayu Candra, 2017) which states that people who use a lot of physical activity in daily life can increase HDL level in the blood thereby improving coronary collateral so that CHD risk can be reduced [11].

Statistical test results showed no relationship between physical activity of DM patients with obesity ( $p=1,000)$. Obesity is a condition of being overweight which is the result of an imbalance between the amount of energy that enters and the energy that comes out through physical activity.[12].

The prevalence of central obesity is higher in samples that do not engage in heavy physical activity. The results of the analysis in this study showed a positive relationship between physical activity and the incidence of central obesity ( $p$ value
$=0.015)$. Physical activity can reduce the incidence of central obesity through the use of fat from the abdominal region, as a result of redistribution of adipose tissue. [13]. A limitation in this study is the small number of samples

\section{CONCLUSION}

Most DM patients aged $\geq 60$ years $(60 \%)$, have elementary education $(74.0 \%)$, have a family history of Diabetes Mellitus (62\%), are female (92\%), have a good diet (58.0\%), have poor physical activity (58\%), have diabetes mellitus blood sugar levels $(84.0 \%)$, obese body mass index $(36 \%)$, have high limit of cholesterol levels (46\%), have central obesity (84\%). Physical activity related to health status including fasting blood sugar levels ( $\mathrm{p}$ value $=$ 0.042 ), not related to cholesterol levels ( $\mathrm{p}$ value $=$ 0.758 ), not related to obesity ( $p$ value $=1,000$ ), related to central obesity ( $\mathrm{p}$ value $=0.015$ ). it is suggested for Heath Care Centre to regularly check monthly blood sugar, cholesterol, anthropometry of the patients.

\section{REFERENCES}

[1] K. RI, Infodatin Pusat data dan Informasi Kementerian Kesehatan RI. Jakarta, 2014.

[2] R. Betteng, “ANALISIS FAKTOR RESIKO PENYEBAB TERJADINYA DIABETES 
MELITUS TIPE 2 PADA WANITA USIA PRODUKTIF DIPUSKESMAS

WAWONASA," J. e-Biomedik, vol. 2, no. $2,2014$.

[3] Badan Penelitian dan Pengembangan Kesehatan Kementerian Kesehatan RI, Riset Kesehatan Dasar (Riskesdas) 2017-2018. Jakarta: Kemenkes RI, 2017.

[4] S. Setyorogo and S. . Trisnawati, "Faktor Resiko Kejadian Diabetes Melitus Tipe II Di Puskesmas Kecamatan Cengkareng Jakarta Barat Tahun 2012," J. Ilm. Kesehat., vol. 5, no. 1, pp. 6-11, 2013.

[5] M. Adnan, T. Mulyati, and J. T. Isworo, "Hubungan Indeks Massa Tubuh (IMT)

Dengan Kadar Gula Darah Penderita Diabetes Mellitus (DM) Tipe 2 Rawat Jalan Di RS Tugurejo Semarang," J. Gizi Univ. Muhammadiyah Semarang, vol. 2, no. 1, pp. 18-24, 2013.

[6] I. Kurniawan, K. Usila, P. Pangkalbalam, and K. B. Belitung, "Diabetes Melitus Tipe 2 pada Usia Lanjut," 2010.

[7] O. Rachmah and L. Ambardini, "AKTIVITAS FISIK PADA LANJUT USIA."

[8] R. A. Karinda, "PENGARUH SENAM SEHAT DIABETES MELLITUS TERHADAP PROFIL LIPID KLIEN DIABETES MELLITUS TIPE 2 DI WILAYAH KERJA PUSKESMAS PATRANG KABUPATEN JEMBER,” Dec. 2013.

[9] J. S. Kekenusa, B. T. Ratag, and G. Wuwungan, "ANALISIS HUBUNGAN ANTARA UMUR DAN RIWAYAT KELUARGA MENDERITA DM DENGAN KEJADIAN PENYAKIT DM TIPE 2 PADA PASIEN RAWAT JALAN DI POLIKLINIK PENYAKIT DALAM BLU RSUP PROF. DR. R.D KANDOU MANADO."

[10] M. Azitha, D. Aprilia, and Y. R. Ilhami, "Hubungan Aktivitas Fisik dengan Kadar Glukosa Darah Puasa pada Pasien Diabetes Melitus yang Datang ke Poli Klinik Penyakit Dalam Rumah Sakit M. Djamil Padang," J. Kesehat. Andalas, vol. 7, no. 3, p. $401,2018$.
[11] P. Penyakit, J. Koroner, and D. I. Poliklinik, “Jantung Rsud Dr Moewardi Surakarta," pp. 11-18, 1998.

[12] O. Relationship, "DIABETES MELITUS TIPE II DI WILAYAH KERJA PUSKESMAS OLAK KEMANG TAHUN 2018," vol. 2, no. 1, pp. 1-11, 2018.

[13] H. Y. Nuraini and R. Supriatna, "Hubungan Pola Makan, Aktivitas Fisik dan Riwayat Penyakit Keluarga Terhadap Diabetes Melitus Tipe 2," J. Ilmu Kesehat. Masy., vol. 5, no. 1, pp. 5-14, 2017. 